\title{
EXPERIENCE AND TRAINING RELATE TO PERFORMANCE CLEAN AND HEALTHY LIVING BEHAVIOR IN CADRE IN THE WORKING AREA OF POASIA PRIMARY HEALTH CARE, KENDARI CITY
}

\author{
Hasmariana $^{1}$, La Ode Saafi ${ }^{2}$, Tasnim Tasnim ${ }^{3}$, Anry Hariadhin Depu ${ }^{4}$ \\ 1,2,3,4 Universitas Mandala Waluya, in Kendari Southeast Sulawesi Province, Indonesia
}

Corresponding Author : Hasmariana

Email : hasmarianarina2@gmail.com

\begin{abstract}
Background:Southeast Sulawesi Provincial data shows that Community life behavior is measured by the number of households with a clean and healthy lifestyle which is based on predetermined indicators. In 2015, the percentage of Clean and Healthy Living Behaviors was 45\%, in 2016 there was an increase of $52 \%$ and decreased in 2017 by $49 \%$ and in 2018 by $46 \%$, while in 2019 there was an increase in the percentage of 53\% again. Based on these data, the coverage was still low because the target was set according to the minimum service standard was $80 \%$. The orientation of community empowerment for health cadres is still insufficient, it is noted that only 36 people have received community empowerment training. The insufficient number of cadres can also make a negative contribution, resulting in the lack of achievement of the primary health care s program Methods:This type of research is a quantitative study, with a cross sectional study approach. The population of this study were 100 people and the samples of this study were 80 cadres in 20 comprehensive health Post in the working area of Poasia primary health care centre in Kendari City. The sampling technique which was used in this study was a simple random sampling.

Results: Based on the results of statistical tests show that the value $\left(X^{2}\right.$ test $)=0.286<X^{2}$ table $=3,841$ ), meaning that there is no relationship between experience and performance of clean and healthy living behavior cadres. The household structures with Chi-square values $\left(X^{2}\right.$ test $)=15,556>$ $\mathrm{X}^{2}$ table $=3,841$, meaning that there is a relationship between training and the performance of clean and healthy living behavior cadres in household arrangements in the working area of Poasia Primary health care centre in Kendari City.

Conclusion:Cadres are expected to play an active role in increasing their knowledge and experience through training activities on cadre performance held by Puskesmas Poasia.
\end{abstract}

Key words: Experience, Training, Cadre, Performance, Healthy, Lifestyle 


\section{INTRODUCTION}

The percentage of households with a clean and healthy lifestyle based on data at the National level in Indonesia is still low, in 2015 amounting to $55.46 \%$, in 2016 amounting to $56.58 \%$ while the target for achieving clean and healthy living behavior for the minimum household structure is $80 \%$. There are 10 indicators in the household structure consisting of (1) delivery by health workers in health facilities, (2) exclusive breastfeeding for babies, (3) weighing children under five, (4) using clean water, (5) washing hands with clean water and soap, (6) use of healthy latrines, (7) eradication of larvae at home once a week, (8) eating vegetables and fruit every day, (9) physical activity every day and (10) the habit of not smoking in the house (1).

Data from the Health Office of Southeast Sulawesi Province also explains the distribution of the percentage of households with clean and healthy living behavior starting from the highest district, namely North Konawe Regency at 94\%, Muna Regency at $81 \%$, Kendari City at $74 \%$, and the lowest percentage is in West Munar Regency, $14 \%$. Broadly speaking, Southeast Sulawesi Province has not reached the target of the SPM set for clean and healthy living behavior coverage, which is $80 \%$, as well as Kendari City, which has quite complete facilities, is the capital of Southeast Sulawesi Province but has not yet been able to achieve the predetermined targets (2).

This study took the research location at Puskesmas Poasia, the reason for choosing Puskesmas Poasia as the research location compared to other Puskesmas in Kendari City because after comparing it with Puskesmas Lepo-Lepo, and Puskesmas Mokoau it is known that the performance of cadres at Puskesmas Poasia has not shown the target of clean and healthy living behavior coverage in the community that is, at least $80 \%$ while the Lepo-Lepo Puskesmas and Mokoau Puskesmas. Apart from the low performance of clean and healthy living behavior cadres at the Poasia Community
Health Center, another reason was that during the Covid-19 pandemic, it was deemed necessary to restrict movement within Kendari City, therefore the research scope of the Regency or the whole Kendari City was not chosen. But of course by not reducing the quality of the results of the research to be carried out.

The role of cadres in health services can be caused by various factors such as internal factors, namely from cadres such as cadre characteristics, knowledge, attitudes, motivation, busyness, while external factors such as providing incentives, rewards, training and so on(3). The knowledge and attitudes of cadres need to be improved with a health promotion strategy for clean and healthy living behavior guidance to cadres and are comprehensive, empowerment in household arrangements is carried out for individuals, families and community groups(4).

\section{METHOD}

This type of research is a quantitative study, with a cross sectional study $\operatorname{approach}(5)$. The location of this research has been carried out in the working area of the Puskesmas Poasia, Kendari City, which was carried out from October to November 2020. The population in this study was 100 people and a sample of 80 people all cadres in 20 Posyandu in the working area of Puskesmas Poasia, Kendari City. The sampling technique used in this study was simple random sampling(6).

\section{RESULTS}

Table-1 shows that of the 80 respondents who have sufficient experience category as many as 37 people $(46.2 \%)$ and less experience category are 43 people (53.8\%).

Table-2 shows that of the 80 respondents based on the assessment of sufficient category training as many as 36 people $(45.0 \%)$ and less category training were 44 people $(55.0 \%)$. 


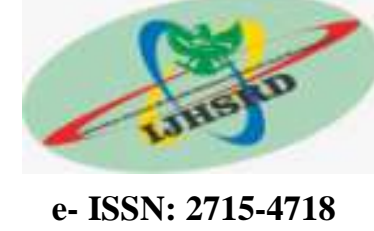

Table-3 shows that among 37 respondents with sufficient experience, there are 16 people $(43.2 \%)$ who have sufficient performance. Meanwhile, of the 43 respondents with less experience, there were 15 people $(34.9 \%)$ who had sufficient performance. This shows that PHBS cadres with sufficient performance are more than respondents with sufficient experience. The results of statistical tests show that the value $(\mathrm{X} 2$ hit $)=0.286<\mathrm{X} 2 \mathrm{tab}=3,841$, meaning that there is no relationship between experience and the performance of clean and healthy living behavior cadres in the household structure in the working area of Poasia, Kendari City. Furthermore, the results of the relationship closeness test show that the value $\varphi$ that is 0.086 or indicates a very weak relationship.
Table-4 shows that among 36 respondents with sufficient category training, there are 23 people (63.9\%) who have sufficient performance. Meanwhile, of the 44 respondents with poor category training, there were 8 people (18.2\%) who had sufficient performance. This shows that PHBS cadres with sufficient performance are more than respondents with sufficient training. The results of statistical tests show that the value $(\mathrm{X} 2 \mathrm{hit})=15,556>\mathrm{X} 2 \mathrm{tab}$ $=3,841$, meaning that there is a relationship between training and the performance of clean and healthy living behavior cadres in household arrangements in the working area of Poasia, Kendari City. Furthermore, the results of the relationship closeness test show that the value $\varphi$ ie 0.467 or indicates a moderate relationship.

Table 1

Distribution According to Respondents' Experience in the Work Area Poasia Health Centre, Kendari City

\begin{tabular}{|c|c|c|c|}
\hline No. & Experience & $\mathrm{n}$ & $\%$ \\
\hline $\begin{array}{l}1 . \\
2 .\end{array}$ & $\begin{array}{c}\text { Enough } \\
\text { Less }\end{array}$ & $\begin{array}{l}37 \\
43\end{array}$ & $\begin{array}{l}46.2 \\
53.8\end{array}$ \\
\hline \multicolumn{2}{|r|}{ Total } & 80 & 100 \\
\hline
\end{tabular}

Table 2

Distribution by Respondent Training in Work Areas Poasia Health Centre, Kendari City

\begin{tabular}{c|c|c|c}
\hline No. & Training & $\mathrm{n}$ & $\%$ \\
\hline 1. & Enough & 36 & 45.0 \\
2. & Less & 44 & 55.0 \\
\hline \multicolumn{2}{l|}{ Total } & 80 & 100 \\
\hline
\end{tabular}

Table 3 
Hasmariana, L.O. Saafi, Tasnim, T., \& Depu, A.H.

DOI: 10.36566/ijhsrd/Vol3.Iss1/67

https://ijhsrd.com/index.php/ijhsrd

e- ISSN: $2715-4718$

Distribution of Experience According to the Performance of Tatanan clean and healthy living behavior Cadres Households

in PoasiaHealth Centre, Kendari City

\begin{tabular}{c|c|c|c|c|c|c|c}
\hline \multirow{2}{*}{ No. } & \multirow{2}{*}{ Experience } & \multicolumn{3}{|c|}{$\begin{array}{c}\text { Clean and Healthy Living } \\
\text { Behavior Cadre } \\
\text { Performance }\end{array}$} & \multicolumn{2}{|c}{ total } \\
\cline { 3 - 7 } & & Enough & \multicolumn{2}{c}{ Less } & \multicolumn{2}{c}{} \\
\cline { 3 - 7 } & & $\mathrm{n}$ & $\%$ & $\mathrm{n}$ & $\%$ & $\mathrm{n}$ & $\%$ \\
\hline 1. & Enough & 16 & 43.2 & 21 & 56.8 & 37 & 100 \\
\hline 3 & Less & 15 & 34.9 & 28 & 65.1 & 43 & 100 \\
\hline & Total & 31 & 38.8 & 49 & 61.2 & 80 & 100 \\
\hline
\end{tabular}

Table 4

Distribution of Training According to the Performance of Tatanan clean and healthy living behavior Cadres Households in Poasia Health Centre, Kendari City

\begin{tabular}{c|c|c|c|c|c|c|c}
\hline \multirow{2}{*}{ No. } & \multirow{2}{*}{ Training } & \multicolumn{3}{|c|}{$\begin{array}{c}\text { Clean and Healthy Living } \\
\text { Behavior Cadre } \\
\text { Performance }\end{array}$} & \multicolumn{2}{|c}{ total } \\
\cline { 3 - 7 } & & Enough & \multicolumn{2}{c}{ Less } & \multicolumn{2}{c}{} \\
\cline { 3 - 7 } & & $\mathrm{n}$ & $\%$ & $\mathrm{n}$ & $\%$ & $\mathrm{n}$ & $\%$ \\
\hline 1. & Enough & 23 & 63.9 & 13 & 36.1 & 36 & 100 \\
\hline 3 & Less & 8 & 18.2 & 36 & 81.8 & 44 & 100 \\
\hline & Total & 31 & 38.8 & 49 & 61.2 & 80 & 100 \\
\hline
\end{tabular}

\section{DISCUSSION}

Relationship of Experience with Clean and Healthy Living Behavior Cadre Performance

This study shows there is no relationship between experience and performance of Clean and Healthy Living Behavior cadres in household arrangements. This is in line with (7) entitled The Effect of Education, Training and Work Experience on Employee Performance in the Marketing Department of PT. Central Santosa Finance (BCA GROUP) Mojokerto Branch. These results indicate that work experience has no effect on cadre performance. The results of the analysis show that the work experience of Clean and Healthy Living Behavior cadres in the household structure is less than or equal to three years, so that the cadres are less able to carry out the tasks given by their superiors to the fullest.

Experience is one of the factors that influence a person's performance in carrying out tasks in order to achieve organizational goals(8). Work experience is an ability that employees have in carrying out the tasks assigned to them. In this study, experience did not provide a significant value to the performance of Clean and Healthy Living Behavior cadres(9). This could have happened because the data from the Poasian Health Center stated that the Clean and Healthy Living Behavior coverage at the Poasia Health Center had not shown any significant changes since three years ago. So even though cadres are known to have work experience that is in accordance with the indicators, because the work experience that is usually applied is still or cannot be developed so that it impacts on the results of Clean and Healthy Living Behavior achievements that are not in accordance with the standards. 
Relationship between Training and Clean and Healthy Living Behavior Cadre Performance

This study shows that there is a relationship between training and the performance of PHBS cadres in household arrangements. So it can be concluded that cadre training is related to the performance of cadres in posyandu activities. Respondents with sufficient training showed more good performance, while respondents with less training showed less performance. The results of this study are in line with research conducted by (10)who found that there was a relationship between cadre training and the performance of posyandu cadres in the work area of Lisi Puskesmas, Tanete Riaja sub-district, Barru district.

States that training is intended so that cadres who have participated are expected to gain knowledge and skills so that they are able to carry out health-minded interventions for the community and someone who has taken non-formal education such as training will have better performance than someone who is less even not getting any training at all(11). In training, in principle, there are learning process activities, both theoretical and practical, aiming at improving and developing academic, social and personal competencies or abilities in the fields of knowledge, skills and attitudes, as well as being useful for training participants in improving performance on tasks or jobs for which they are responsible(12).

Effective training must be oriented towards results (goals) and processes (the ability of the organization to adapt and survive)(13). The results of an effective training process will be able to make an organization well able to carry out its planned programs systematically in an effort to achieve the results or objectives that have been set(14). In other words, a training is called effective if the training can produce human resources whose abilities, skills, and attitude change are more independent. In this way will also affect the quality of performance.

\section{CONCLUSION}

Cadres are expected to play an active role in increasing their knowledge and experience through training activities on cadre performance and the Puskesmas Poasia is expected to be selective by determining the criteria needed in selecting cadres so that the purpose of appointing cadres, namely to increase Clean and Healthy Living Behavior coverage, can be achieved.

\section{REFERENCES}

1. Ministry oh Health of Republic of Indonesia. Indonesian Health Profile in 2015. Jakarta: Kementerian Kesehatan Republik Indonesia. 2015 (Indonesia).

2. Health Department of Southeast Sulawesi Province. Distibution of Healthy life and clean behaviour data In Kendari. Sulawesi Tenggara. 2020 (Indonesia).

3. Putri IM, Surjadi LM. The relationship between internal dan external factors and regular antanal treatment. Jurnal Biomedika dan Kesehatan. 2019;2(1):27-33 (Indonesia).

4. Ministry oh Health of Republic of Indonesia. Health ministry decision number 1995/Menkes. SK/XII/2011 about Antropometry standar of body mass index measuremen. 2011 (Indonesia).

5. Mackey A, Gass SM. Second language research: Methodology and design: Routledge; 2015.

6. Sugiyono. Nonparametrict statistics for research. 2015.

7. Alfin MR, Nurdin S. The effect of Atmosphere store to clien satisfaction which affects to clien Loyality. Jurnal Ecodemica: Jurnal Ekonomi, Manajemen, dan Bisnis. 2017;1(2):249-58 (Indonesia).

8. Rakhmatullah AE, Hadiati S, Setia KA. The effect of competency, work experiment and work Etos to staff 
Hasmariana, L.O. Saafi, Tasnim, T., \& Depu, A.H. DOI: 10.36566/ijhsrd/Vol3.Iss1/67

https://ijhsrd.com/index.php/ijhsrd

$\begin{array}{lll}\text { performance } & \text { in } & \text { Dimediasi } \\ \text { Profesionalisme } & \text { in } & \text { Education }\end{array}$ department in Probolinggo District. Jurnal Ekonomi dan Manajemen. 2018;19(1).

9. Aldi Y, Susanti F. The effect of work Stress Kerja and work motivation to staff's work prestige in PT. Frisian Flag Indonesia in Padang. 2019.

10. Napirah MR, Rahman A, Tony A. Factors of health service usage in Tambarana Health Care in Poso Pesisir Utara Sub-district, Poso District. Jurnal Pengembangan Kota. 2016;4(1):29-39.

11. Daulay $\mathrm{H}$. The effect of education and training to civil servance performance in Badan Pendapatan Pengelolaan Keuangan dan Asset Daerah in Padang Lawas District. 2017 (Indonesia).

12. Elizar E, Tanjung $\mathrm{H}$. The effect of training, competency, and environment to staff performance. Maneggio: Jurnal Ilmiah Magister Manajemen. 2018;1(1):46-58.

13. Setiawan H. Training Management. Aktualita: Jurnal Penelitian Sosial Keagamaan. 2018;8(2):32-47.

14. Fadhilah AT. The effect of budgeting based on performance to effectivity in Purabaya-Jati-Saguling street development project in Bandung Barat District (Survey in Department of general work and room setting in Bandung Barat District): Universitas Widyatama; 2017. 